\title{
A Stage Set for Disaster: For-Profit Nursing Homes, Federal Law, and COVID-19
}

\author{
David Ray Papke, JD, PhD \\ Professor of Law, Marquette University Law School \\ David.papke@marquette.edu
}

\begin{abstract}
This article exposes the tragic relationship between for-profit nursing homes and the spread of COVID-19 in those facilities. For-profit nursing homes came to dominate nursing-home care in the United States in the second half of the twentieth century. However, for-profit nursing homes on average provided care which was inferior to the care provided in state-run and nonprofit nursing homes. Congress attempted to address the problems in nursing homes in the final decades of the twentieth century, but massive statutes and abundant regulations served mostly to legitimize for-profit nursing homes. COVID-19 then underscored the flaws in the legally sanctioned, for-profit nursing homes, as thousands died within the problematic institution's walls.
\end{abstract}

Keywords: long-term care, Medicare, Medicaid, real estate investment trust, involuntary discharge, patient dumping, infection control, nursing aide, assisted living, Nursing Home Reform Act, Residents' Bill of Rights, infection preventionist

\section{RESUMEN}

Este artículo expone la trágica relación entre los hogares de ancianos con fines de lucro y la propagación del COVID-19 en esas instalaciones. Los hogares de ancianos con fines de lucro llegaron a dominar la atención en hogares de ancianos en los Estados Unidos en la segunda mitad del siglo XX. Sin embargo, los hogares de ancianos con fines de lucro en promedio brindaban atención que era inferior a la atención brindada en los hogares de ancianos administrados por el estado y sin fines de lucro. El Congreso intentó abordar los problemas en los hogares de ancianos en las últimas décadas del siglo XX, pero los estatutos masivos y las abundantes regulaciones sirvieron principalmente para legitimar los hogares de ancianos con fines de lucro. COVID-19 luego subrayó las fallas 
en los asilos de ancianos con fines de lucro sancionados legalmente, ya que miles de personas murieron dentro de los muros de la institución problemática.

Palabras clave: atención a largo plazo, Medicare, Medicaid, fideicomiso de inversión en bienes raíces, alta involuntaria, abandono de pacientes, control de infecciones, asistente de enfermería, vida asistida, Ley de reforma de hogares de ancianos, Declaración de derechos de los residentes, prevención de infecciones

\section{为灾害而设的舞台：营利性疗养院、 联邦法和 2019 冠状病毒病}

\section{摘要}

本文研究了营利性疗养院与2019冠状病毒病（COVID-19）在 这些设施中的传播之间的悲剧关系。营利性疗养院于 20 世纪 下半叶开始在美国的疗养院护理中占据主导地位。不过, 营 利性疗养院平均提供的护理曾次于国营疗养院和非营利性疗 养院。国会曾试图在20世纪最后几十年里解决疗养院产生的 问题，但大量的法规和规制基本只是对营利性疗养院进行合 法化。如今, COVID-19强调了受法律批准的营利性疗养院所 出现的问题，因为成千上万的人在这类有问题的机构中去 世。

关键词：长期护理, 联邦医疗保险, 医疗补助, 不动产投资 信托, 非自愿出院, 抛弃病人, 感染控制, 护理助手, 辅助 生活, 《疗养院改革法》, 《居民权利法案》, 感染预防人 员

\section{Introduction}

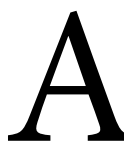

$\mathrm{n}$ issue of the Journal of Elder Policy devoted to the impact of COVID-19 must pay special attention to what has transpired in American long-term care facilities. The death tolls within these facilities and especially within nursing homes during the
COVID-19 pandemic have been staggering. After only four months of the pandemic, some 51,000 people living or working in nursing homes had died (Silver-Greenberg \& Harris, 2020). Six months into the pandemic, an estimated one in five nursing-home residents had contracted the disease, and the pandemic's nursing-home deaths account- 
ed for 40 percent of all the coronavirus deaths in the entire United States (Barker, 2020). Ten months into the pandemic, 136,000 nursing-home residents had died, accounting for 36 percent of all virus-related deaths (Robbins, 2021). In the words of two reporters for the New York Times, "More than any other institution in America, nursing homes have come to symbolize the deadly destruction of the coronavirus" (Silver-Greenberg \& Abrams, 2020, p. 1).

Some of those who died in nursing homes had pre-existing conditions that had put them near death's door, but most of the deaths related to problems in nursing-home care and operations. Commentators have pointed to everything from unsanitary shared bathrooms to the lack of personal protective equipment for nursing-home staff (Ferré-Sadurni \& Harris, 2020). Whatever the particular problems, infections spread rapidly in nursing homes. Transmission occurred via undetectable droplets passing through the air, and residents as well as staff were extremely vulnerable. Nobody seemed to know how the spread could be stopped.

Without discounting the specific problems that led to the spread of COVID-19 infections in nursing homes, might there be a more fundamental cause for the disaster in American nursing homes? Might the explanation for the huge number of COVID-19 deaths in nursing homes be for-profit nursing homes in and of themselves? These nursing homes came to dominate nursing-home care in the United States in the second half of the twentieth cen- tury and today make up the great majority of all nursing homes (Goldstein \& Gebelhoff, 2020). Numerous studies have found that these facilities on average tend less satisfactorily to the needs of their residents than do state-run or nonprofit nursing homes (Center for Medicare Advocacy, 2012).

The inferior care provided by for-profit nursing homes eventually came to the attention of the public and to government officials. Congress enacted major legislation in an attempt to improve nursing-home care, and administrative agencies promulgated bushels of regulations to buoy the laws. Unfortunately, these laws and regulations did more in the long run to legitimize for-profit nursing homes than to make them better. In a way that was unanticipated by legislators and regulators, law ultimately locked inferior for-profit nursing-home care into place.

The article puts for-profit nursing homes, the legal control of them, and the COVID-19 pandemic in a rough historical continuum. The first section examines the rise of the for-profit nursing home, underscoring the impact of profit-seeking on nursing-home care. The second section outlines the federal laws and regulations designed to improve nursing homes and then discusses the reasons for the failure of these laws and regulations. The third and concluding section points out why the for-profit nursing home as a socio-legal construct was unable to protect residents from COVID-19. Thousands of nursing-home residents have officially died from COVID-19, but legally sanc- 
tioned, for-profit nursing homes set the stage for the disaster.

\section{For-Profit Nursing Homes}

The nursing home has evolved into an important and profitable institution in American life. Ranging from small vest-pocket facilities to sprawling suburban complexes, nursing homes currently number approximately 15,400 . They house at least 1.5 million people, 85 percent of whom are over 65 years of age and 70 percent of whom are over 75 (Howley, 2020). In the present, over 70 percent of all nursing homes are operated for profit (Harrington et al., 2011), and, like other businesses, for-profit nursing homes attempt to hold down their costs in order to increase their profits. Unfortunately, this for-profit approach is especially unlikely to provide safe and conscientious care.

The precursors of the modern for-profit nursing home were the almshouses and poorhouses of an earlier era. They housed various numbers of delinquent, sick, disabled, drunken, and older people, but these groups did not necessarily share the same concerns and maladies. Around the turn of the twentieth century, reformers began to argue that older adults who neither required hospitalization nor were dying could benefit from facilities providing treatment just for them (Rincon del Rio, 2017).

The reformers were for the most part altruistic, but the argument for special long-term care facilities for old- er adults also dovetailed with a growing sense that it might be best to separate older adults from the rest of the general population. While older adults had generally been respected and viewed positively on the family farm during the first half of the nineteenth century, the view of older adults grew increasingly negative as the United States industrialized and urbanized in the final decades of the century. Employers did not perceive older adults as valuable employees, and society in general began equating old age with disease and poverty. As the twentieth century dawned, many came to see older adults as more of a burden than a resource. One way to ease the burden was to put older adults together in their own place (Laws, 1993).

The notion of special places for older adults increased during the 1930s as the Great Depression destroyed the nation's economy. Aging parents and relatives seemed to some an especially difficult responsibility, and the idea that these people could reside in facilities other than the home grew more appealing. The available facilities went by different names-old people's homes, rest homes, board-and-care homes-but gradually the name "nursing home" became the most popular, at least in the United States.

Following World War II, the number of nursing homes and the size of nursing-home populations continued to grow as government became increasingly willing to pay for all or part of residents' care. Between 1950 and 1980 , for example, the number of nursing homes doubled, and the number of nursing-home beds tripled (Hawes \& 
Phillips, 1986). The strongest spur for growth was Congress's enactment of the Medicare and Medicaid programs in the mid-1960s. ${ }^{1}$

\section{Medicare and Medicaid pay-} ments were especially enticing for the owners and developers of for-profit nursing homes, and although nonprofit organizations continued to run nursing homes, for-profit businesses came quickly to operate most American nursing homes (Goldstein \& Gebeloff, 2020). In the opinion of most, the shift away from nonprofit nursing homes was not for the better. The non-profits were usually run by organized religions or by ethnic or occupational associations, and they catered to some extent to homogenous groups of patients and residents with shared values. Often, the nonprofit nursing homes had a sense of mission (Adler, 2003). The for-profit homes, by contrast, were in fact run for profit, and profit-seeking often resulted in less attentive and committed care.

What's more, it should be emphasized that for-profit nursing homes are not for the most part small momand-pop operations. They are often parts of large complexes that also offer independent living, assisted living, and memory care. Some nursing homes are units in multi-facility chains, and many are parts of large corporate enterprises. Even the most sophisticated of researchers have admitted how difficult it is to figure out how they are organized and structured (Stevenson et al., 2013).
The country's biggest nursinghome business appears to be Genesis HealthCare, and it operates more than 500 nursing homes with 42,000 beds in 26 states (Goldstein, 2020). With corporate headquarters near Philadelphia, Genesis HealthCare is organized as a holding company, that is, it owns outstanding stock in other companies and for the most part does not produce goods and services itself (Fortune 500, 2020). One big advantage of a holding company is that the various companies within the business are technically separate from one another, and large-scale losses incurred by one company are unlikely to translate into successful claims on the assets of the other companies. What's more, the existence of separate companies within the holding company has the effect of limiting tort claims for negligent injuries to just the assets of a single company. Parts of the asbestos businesses took advantage of this limited liability when faced by large lawsuits in an earlier era (Dearborn, 2009), and one suspects holding companies such as Genesis HealthCare could do the same with lawsuits citing flawed nursing-home care.

Only the very largest of nursing-home businesses are technically organized as holding companies, but as already noted, most have complex and obfuscating organizational structures. Some of the larger nursing-home businesses have no fewer than five levels of ownership (Harrington et al., 2011). Should a resident or the family of a res-

1 Although Medicare and Medicaid payments are crucial in the growth of the nursing-home industry, it bears underscoring that neither program has primary responsibility for nursing homes' management or quality of care (Grabowski, 2007). 
ident want to sue a nursing home because of perceived mistakes and mismanagement, it is difficult to know whom one might sue (Rau, 2020; Stevenson, et al., 2013).

One distinctive feature of for-profit nursing homes is their reliance on real estate investment trusts (REITs). These REITs are corporations that invest in real estate and receive tax exemptions from the corporate income tax if they meet certain requirements regarding assets, sources of income, and dividends. The largest nursing home chains have separated their management from their assets and placed the assets into REITs. This, in turn, allows the largest nursing home companies to reduce or even eliminate their tax bill (Harrington et al., 2011). In the present, six of these REITs are the "landlords" for over 1500 nursing homes (Goldstein, 2020).

Nursing-home businesses also profit when individual nursing homes and chains of nursing homes buy goods and services from companies in which the parent businesses have a financial interest or which they completely control. Indeed, nearly three-quarters of nursing homes make these types of purchases (Rau, 2017). The market for goods and services is sizable not only because of the large number of nursing home residents who need the goods and services but also because residents continue to need the goods and services for surprising lengths of time. ${ }^{2}$ Perhaps needless to add, the for-profit nursing homes often pay their affiliated provid- ers more than these providers could charge in an open market (Rau, 2017).

The individual operators or chains, meanwhile, profit from what the residents pay for their housing and care through Medicare and Medicaid, personal savings, or private insurance plans. Medicare pays for roughly 18 percent of what is charged in nursing homes, and Medicaid pays for roughly 45 percent. The rest is paid for from personal savings and private insurance benefits (Harrington, 2011).

As befits bottom-line businesses, for-profit nursing homes are prepared to evict tenants if they do not pay their bills. These "involuntary discharges," as they are officially known, occur thousands of times annually, often with dire consequences. Evicted tenants can receive physical injuries while leaving their facilities, suffer psychologically when ties to trusted staff and fellow residents are severed, and become disoriented if relocated to distant, unfamiliar places. Some discharged tenants find themselves in homeless shelters andin the worst of scenarios-die while being moved out (Grant \& Smetanka, 2020; Silver-Greenberg \& Harris, 2020).

Most discharges are not illegal, and recognized justifications exist for evicting or discharging a nursing-home resident:

1. a resident needs a higher level of care

2. a resident no longer needs nursing-facility care

2 The average stay in a nursing home has grown to 4.5 years (Howley, 2020). 
3. a resident endangers other residents' safety

4. a resident endangers others' health

5. nonpayment

6. the facility is closing

On the surface, these stated reasons for eviction or discharge in and of themselves are not objectionable (Heiser, 2020).

The problem, meanwhile, is that for-profit nursing homes evict for reasons other than the established ones and sometimes do so in sneaky ways. For example, Rockport Healthcare Services, which manages California's largest chain of for-profit nursing homes, has repeatedly been cited by California authorities for illegal evictions (SilverGreenberg \& Harris, 2020).

Critics say that the nursing homes tend to evict low-income, longer-term residents who receive Medicaid in order to make room for shorter-term rehabilitation patients who are covered by Medicare or for relatively affluent residents who can rely on private insurance policies. Medicare and private insurance policies almost always reimburse nursing homes at a higher rate than does Medicaid, and nursing homes can make extra money by replacing one type of resident for the other (Engelhart, 2019). One sneaky way to accomplish this is through what is called "patient dumping." This happens when a nursing home transfers a resident to a hospital ostensibly for needed treatment and then refuses to readmit the resident when the treatment is com- plete or is not really needed after all (Heiser, 2020).

While the sophisticated nursing-home business has garnered large profits, the for-profit approach has not significantly improved either the living conditions in nursing homes or the quality of care received by nursing-home residents. Indeed, the for-profit nursing homes routinely "skimp on quality" (Goldstein et al., 2020, B6). According to investigative journalists, the for-profit nursing homes disproportionately lag behind the non-profit nursing homes across a broad array of measures for quality (Goldstein et al., 2020). Like other businessmen, after all, the owners of nursing homes seek to hold down their costs in hopes of increasing their profits. The previously mentioned Genesis HealthCare, for example, has a "spotty record" and has agreed to pay the federal government almost $\$ 54$ million for providing substandard care at several of its nursing homes (Barker, 2020, p. A11).

The very design of most nursing homes relates to business concerns. Most nursing homes resemble small hospitals. They feature lounges, recreation areas, and dining rooms at the end of corridors along which individual and double rooms line up. If nursing homes instead had suites and small apartments, the occupants of each suite or apartment could interact in mutually supportive ways. Regrettably, suites and apartments of this sort would be more expensive to build and rent. With the traditional design, meanwhile, the residents understandably feel more like 
they are in hospitals than in homes (Margolies, 2020).

The particular practice in nursing homes that has seemed especially problematic has been infection control. Each year, studies have shown, the approximately 1.4 million people living in nursing homes have 3.8 million infections resulting in 200,000 hospitalizations and 380,000 deaths (Drucker \& Silver-Greenberg, 2020; Gonzales, 2020). The most common varieties are gastroenteritis, skin infections, and respiratory infections such as influenza and pneumonia. These infections spread quickly within nursing homes because residents are closely quartered, share sinks and toilets, and eat together (Gonzales, 2020).

Here, too, the for-profit nursing homes' determination to control costs contributes to the problem. The best way to stop the spread is the development of and adherence to infection control programs, but nursing homes and especially for-profit nursing homes have long been notorious for their inferior infection control (Gonzales, 2020). Why do for-profit nursing homes have poor records? Effective infection control programs are expensive and can cut into profits.

The for-profit nursing home industry has also tried to hold down costs associated with staffing. According to one commentator, the large corporations and holding companies that dominate the nursing-home industry are likely to "sacrifice proper staff training and other quality measures to make a profit at the residents' expense" (Nursing
Home Abuse, 2020). The federal Centers for Medicare and Medicaid rated three quarters of New York City's nursing homes "below average" or "much below average" when it came to staffing (Leland, 2020, p.28). Because of staff shortages and shortcomings, friends and family members often become crucial caregivers for the residents, helping with personal hygiene, washing clothes, and changing bedding.

The nursing aides themselves are predominately immigrants or members of minority groups, and they are usually paid the minimum wage and work without benefits (including but not limited to sick days). An estimated 38 percent need public benefits in the form of welfare, food stamps, and housing subsidies in order to make ends meet. Their lengthy shifts sometimes stretch for twenty-four hours, and the aides' fatigue from long shifts no doubt contributes to work tasks being overlooked or done poorly. Since the wages from a nursing home are often too low to support a family, many aides have additional part-time jobs, and fatigue from these part-time jobs can also contribute to carelessness and inattentiveness (Kim, 2020).

One especially disturbing result of relying on poorly trained, overworked, and underpaid staff is the abuse of residents. Stressed, working long shifts, and worried about making ends meet, nursing home staff too frequently abuse the residents financially, physically, or some combination of both. Individual reports, pictures, and videos of this abuse have shocked the 
public for the past twenty years, with one particularly troubling video showing a group of nursing-home staffers eagerly taunting a 91-year-old dementia patient (Fieldstadt, 2019). Two out of three nursing-home staff members have admitted they have abused residents, and one in three nursing homes in the United States have been cited for abuse problems (Nursing Home Abuse, 2020). A 2014 survey of over 2,000-home residents found that 44 percent of those surveyed had been abused and that 95 percent had either experienced or witnessed neglect (Weinmeyer, 2014).

One indicator that for-profit nursing homes were providing penurious and unsatisfactory accommodations and care was the rise of the assisted living industry in the late 1980s and subsequently. While it is difficult to say exactly when assisted living facilities originated, one commentator has noted the use of the phrase "assisted living" in 1985, when Oregon launched a study of residential possibilities for Medicaid recipients (Wilson, 2007). The phrase subsequently surfaced in print and at professional meetings, often in a quite idealistic vein. The promoters of assisted living hoped that it would provide an alternative to for-profit nursing homes by being more genuinely residential, expanding service options, and stressing consumer-centered care rather than capitulating to profit-seeking (Wilson, 207). It is uncertain whether the assisted-living industry reached these goals, but the industry's ability to indict and the approach and practices of nursing homes contributed to assisted living's commercial success.

\section{Nursing-Home Law}

I $\mathrm{n}$ the final decade of the twentieth century, after years of complaints about nursing homes' operations, federal lawmakers and regulators attempted to address nursing-home problems. The resulting laws earnestly exhort nursing homes to do things in certain ways, and the elaborate regulations offer detailed prescriptions and proscriptions, with sanctions to boot. Yet weaknesses in the laws and regulations themselves and also the halting enforcement of those laws and regulations prevented the laws and regulations from impacting nursing homes in fundamental ways. Despite the lawmakers' best intentions, nursing homes remained dangerous places in which to age and to battle serious medical problems, and in the end the laws and regulations had the effect of legitimizing the nursing homes, that is, making a problematic institution acceptable and permissible.

While many individual states have specialized nursing-home statutes, the most ambitious and important legislation related to nursing homes is the federal Nursing Home Reform Act (NHRA). Originally enacted in 1987, the NHRA applies not only to the for-profit nursing homes that dominate nursing-home care but also to nursing homes in general. Amended and expanded many times since its enactment, the NHRA without a doubt remains the starting point in any consideration of nursing-home law (Nursing Home Reform Act, 1987). 
In general, the NHRA mainly lists and briefly describes the arrangements and services a legitimate nursing home should provide its residents. The services include periodic assessments, comprehensive care plans, skilled nursing, counseling, rehabilitation, and dietary advice. In a nod to the complicated psychological and social problems of many nursing-home residents, the NHRA also says a nursing home with more than 120 beds must have a fulltime social worker on staff. More generally, the NHRA says a nursing home "must care for its residents in such a manner and in such an environment as will promote maintenance or enhancement of quality of life for each resident" (Quality of Life; Nursing Home Reform Act, 1987, 42 U.S.C. 1396r(b)(1)(A)). The NHRA also entreats nursing homes to "provide services to attain or maintain the highest practicable, physical, mental, and psychosocial well-being of each resident" (Scope of Services and Activities under Plan of Care; Nursing Home Reform Act, 1987, 42 U.S.C 1396r(b)(2)).

To buoy these promises, Congress also approved a Residents' Bill of Rights (RBR). It is intriguing that Congress would attach the label "rights" to what is listed in the RBR. A "right," after all, has high standing in the law. It is much more than a wish or a preference. A "right" is more protected than a wish or a preference. If a person has a right, that person is truly entitled to whatever that right might be. Others are supposed respect it, and surely the government should not be able to take it away. That having been said, one suspects Congress did not reflect at any length on what constituted a "right," and the term was probably used just to add some clout and prestige to what was listed in the RBR. ${ }^{3}$

The RBR for the most part lists the options and protections residents in nursing homes should have. According to the RBR, residents should have the "right" to voice grievances, to participate in the review of care plans, and to be fully informed in advance about any changes in care, treatment, or change in status. The RBR also says more generally that the residents of nursing homes should have the "right to be treated with dignity" (Klauber \& Wright, 2001).

While the words in the original NHRA and the RBR are for the most part copacetic, the words do not explicitly require specific acts or ban specific kinds of conduct. As already noted, these laws are largely exhortative, that is, they express a hope that nursing homes will provide careful and humane care. The NHRA and RBR urge nursing homes to be attentive and respectful institutions, but they do virtually nothing to guarantee that they will be.

Federal nursing-home regulations, by contrast, direct and prohibit specific acts and behaviors. Traditional sociologists, without intending to be pejorative, might characterize the function of the nursing-home regulations as a matter of "social control" (Barkan,

3 Some argue that health care should be understood as a right rather than a privilege, and Congress, without realizing it, flirted with that idea when it called what was listed in the RBR "rights." 
2009, pp.5-6; Black, 1976, p. 106). Regulations of this sort are common in a modern country such as the United States, and they certainly have the potential to prompt compliance (Papke, 2019).

Potential of this sort notwithstanding, the federal nursing-home regulations are at points so detailed as almost to invite noncompliance (Requirements for States and Long-Term Care Facilities, 1989). The Centers for Medicare and Medicaid (CMS), a sprawling federal agency within the United States Department of Health and Human Services, is authorized to change the regulations, and it has frequently taken advantage of that authorization. Consumer groups and especially business interests are able to influence the process, and the CMS is of course always mindful of the political concerns and preferences of the White House.

One can get some sense of how detailed, lengthy, and comprehensive the regulations are by looking, for example, at what is required in residents' rooms. The requirements for rooms can be found in one of the nine subsections of the regulations concerning the physical environment of nursing homes. After a blanket statement to the effect that rooms in nursing homes must be designed and equipped for adequate nursing care, comfort, and privacy, the subsection describes an acceptable room. It must accommodate no more than four people, measure at least 80 square feet per resident, have direct access to an exit corridor, be designed to assure visual privacy for each resident, have curtains suspended from the ceiling extending around each bed, include at least one window, and have a floor at or above grade level. In addition, each room must include a bed of proper size and height for each resident, bedding appropriate to the weather and climate, functional furniture, and individual closet space with racks and shelves which the resident can reach (Physical Environment, Resident Rooms; Requirements for States and Long-Term Care Facilities, 1989, 42 C.F.R. \$483.90).

Clearly, a regulator has given thought to what a nursing-home room should be like, and one can imagine a nursing-home developer or director scrambling to meet all the requirements. However, the final section of the provision might give one pause. If a nursing home is found not to meet the requirements, the facility might request an exemption if its variations from the requirements "will not adversely affect the residents' health and safety" (Physical Environment, Resident Rooms, Exceptions; Requirements for States and Long-Term Care Facilities, 1989, 42 C.F.R. $\$ 483.90(e)(3))$.

The CMS itself does not grant exemptions of this sort or in general monitor nursing homes and nursing-home care for compliance with the numerous regulations. According to federal law, monitoring and oversight are instead to be undertaken by the individual states (Klauber \& Wright, 2001). It is anticipated that the states will conduct unannounced surveys and interview residents at nursing homes at least every 15 months. The states must also con- 
duct so-called "target investigations" in response to complaints about specific nursing homes (Klauber \& Wright, 2001).

If a survey or investigation reveals that a nursing home is out of compliance, a nursing home has an opportunity to correct the deficiency before sanctions are imposed. Sanctions might include mandatory in-service training for the staff, monetary penalties, and even complete termination of the nursing home's operations. Especially noteworthy, meanwhile, is the possibility that a nursing home would lose its eligibility to receive Medicare and Medicaid payments for its residents. This would be a death blow for most nursing homes.

Sadly, the monitoring and oversight process has hardly eliminated substandard care. The Senate Committee on Aging, for example, discovered that 30 percent of California's nursing homes had violations of the regulations that had actually harmed residents or put them in immediate danger. Only 2 percent of the California facilities, meanwhile, were found to have no deficiencies (Wright, 2001). Not surprisingly, the deficiencies are greatest among the for-profit nursing homes that dominate the nursing-home industry (Harrington, 2011). A 2001 study found that for-profit facilities were cited by regulators for deficient care 46.5 percent more frequently than non-profit facilities (Adler, 2003).

The overall ineffectiveness of federal law and regulations derives in some large part from the states' halting efforts to oversee and monitor nursing homes. State surveys, it seems, are often sporadic and incomplete, and serious problems often go undetected. Even when detection occurs, state officials frequently do not demand the necessary corrections or mete out the appropriate sanctions. In the area of eviction or discharge, for example, inspectors rarely cite nursing homes for violating the regulations, and even when they do issue citations, they generally do not have meaningful penalties attached to them. In fact, some penalties for improper evictions or discharges are so inconsequential that nursing homes simply say they will "take the hit" rather than trying to comply (Grant \& Smetanka, 2020, p. 202). According to Alison Hirschel, a lawyer for Michigan's oversight program, "We have been seeing these kinds of illegal discharges all the time because nursing homes seem to have figured out that they will rarely, if ever, be penalized" (Silver-Greenberg \& Abrams, 2020, p. 6).

It would be an overstatement to say that the nursing-home industry has taken over the regulations and their enforcement, but it is advisable to lower whatever expectations one might have for the regulations. David Stevenson, a health policy analyst at the Vanderbilt University School of Medicine says, "Because of its orientation, nursing home quality assurance is better equipped to assure a minimal floor than it is able to incentivize excellent care" (Stevenson, 2018, n.p.).

Despite the leniency manifested in the monitoring and oversight system, 
for-profit nursing homes wanted even less-demanding regulations. In particular, the American Health Care Association, a large nursing home trade association, began lobbying President-Elect Trump a whole month before he took the oath of office in 2017 (Edelman, 2018). Then, in a build-up to the 2020 campaign, nursing-home operators honored President Trump at a fund-raising dinner and contributed more than $\$ 3$ million to his election campaign (Drucker \& Silver-Greenberg, 2020). During the dinner President Trump offered special praise for Eliezer Scheiner, the owner of 22 nursing homes, and Scheiner himself contributed $\$ 750,000$ to the Trump campaign (Drucker \& Silver-Greenberg, 2020).

The Trump Administration's reaction to this support could be seen as part of Trump's much-ballyhooed call for "deregulation," and, indeed, his deregulation directives eventually reached many parts of the federal regulations. Some might find deregulation in itself appealing, much as some might think the woods are more attractive if rotted, fallen timber is removed. But it is also worth underscoring that the deregulation effort was not merely a matter of getting rid of regulations across the board. The regulations cast as noxious or undesirable were frequently those perceived to reduce certain businesses' and industries' profits. Deregulation in the nursing-home area was thought to be good for the business pursuits of the nursing-home industry.

The regulatory changes supported by the Trump Administration for the nursing-home industry included less oversight, smaller fines for deficiencies, and limitations on lawsuits by residents and their families. According to the Centers for Medicare and Medicaid, these changes would save the nursing-home industry approximately $\$ 640$ million annually (Drucker \& Silver-Greenberg, 2020). Toby Edelman, a lawyer at the Center for Medicare and Medicaid Advocacy, said the regulatory changes amounted to "a gift for the industry" (Drucker \& Silver-Greenberg, 2020, p. B6).

In addition, the Trump Administration set out to make the regulations related to infection control less stringent (Infection Control; Requirements for States and Long-Term Care Facilities, 1989, 42 C.F.R. \$483.80). These regulations require nursing homes to have formal infection prevention and control programs. By law, the programs have to include a system for preventing, identifying, reporting, investigating, and controlling infections for all residents and staff. Furthermore, the standards, policies, and procedures for the program have to be in writing, reviewed annually, and spell out a nursing home's "system of surveillance" (Infection Control; Nursing Home Reform Act, 1989, 42 C.F.R. $\$ 483.80$ ). The regulations even instruct nursing-home personnel to "handle, store, process, and transport linens so as to prevent the spread of infection" (Infection Control; Requirements for States and Long-Term Care Facilities, 1989, 42 C.F.R. \$483.80).

The provision in the infection control regulations that struck the 
Trump Administration as especially excessive and costly related to so-called "infection preventionists" (Infection Control; Requirements for States and Long-Term Care Facilities, 1989, 42 C.F.R. \$483.80). According to the regulations, each nursing home was required to have a designated infection preventionist, who worked at least parttime at the facility; was professionally trained in nursing, medical technology, microbiology, epidemiology, and or another related field; and had completed specialized training in infection prevention and control (Infection Control; Requirements for States and LongTerm Care Facilities, 1989, 42 C.F.R. $\$ 483.80$ ).

The regulatory requirement for an infection preventionist might have been especially irksome to the Trump Administration because the requirement had been initiated by the Obama Administration in 2016. Few innovations and initiatives of the Obama Administration won favor within the Trump Administration (Eilperin, 2018). The nursing-home industry may not have been as hostile to the policies and programs of the Obama Administration as was the Trump Administration, but, with cost-cutting always foremost in mind, the industry supported the Trump Administration's efforts. Requiring nursing homes to have an infection control preventionist on staff was taken to be burdensome and unnecessary by the industry (Khimm \& Strickler, 2020).

It is difficult to imagine a more obvious example of the nursing-home industry and government officials disregarding the needs of nursing-home residents. As noted earlier, the spread of infections is a major concern within nursing homes. Lapses in infection control, after all, have been cited as the most frequent type of health violation in nursing homes (Khimm \& Strickler, 2020). Between 2017 and 2020, 9,372 nursing homes were cited for infection control lapses, and 3,528 were cited more than once (Rau, 2020). Residents of nursing homes would benefit from more rather than less infection control, and it surely would not hurt the cause if an infection preventionist was on staff.

The results of the 2020 election have at least put the attempt to roll back requirements for nursing homes and to roll back government regulations in general on hold, but the extended episode involving nursing-home regulations concerning infection control illustrates how much business interests and political preferences might influence the drafting, change, and enforcement of nursing-home regulations. It is always possible that an effort to make nursing homes better places in which to live and seek medical treatment can wash up on the shoals of business influence and political maneuvering.

In general, nursing-home laws and regulations have had only very limited impact. Yes, some of the problems that are most bothersome for nursing-home residents-bed sores, a reliance on urinary catheters, and the use of physical restraints-have been reduced (Zheng \& Grabowski, 2004). But the major legislation is only exhor- 
tative, detailed regulations are routinely circumvented, and monitoring is spotty. The contemporary nursing home remains an institution that largely puts profit before care and in the process fails to satisfactorily serve its residents. Nursing-home laws and regulations did not succeed in altering the fundamental character of the for-profit nursing home as an institution.

What's more, the efforts of Congress and of the federal and state regulatory agencies have had the effect of legitimizing for-profit nursing homes. Lawmakers, after all, do more than prescribe and proscribe; they also recognize and countenance. Congress and the regulatory agencies provided nursing homes not so much with a stamp of approval as with tacit acceptance under law. Come respectably close to what we have set out, the lawmakers and regulators appear to be saying, and you can carry on with your business. Without necessarily reflecting on it, Congress and the regulatory agencies encased for-profit nursing homes in a legal regimen that has served to perpetuate the nursing homes' problematic practices.

\section{COVID-19}

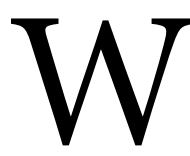

hen COVID-19 swept across the United States in early 2020 , certain sites and institutions proved especially vulnerable to it. Perhaps no single institution was more vulnerable than the legally sanctioned, for-profit nursing home. Nursing homes became veritable COVID-19 death traps for their sick and elderly residents.
Almost as soon as the COVID-19 pandemic began, it became evident that normal investigations of nursing homes would be ineffective and that residing in a legally sanctioned for-profit nursing home would be potentially disastrous for residents. Inspectors cleared 80 percent of all nursing homes during the first six months of the pandemic, but nursing homes with clean bills of health nevertheless had 290,000 infections and 43,000 deaths among the residents and staff (Cenziper et al., 2020). Even the relatively small number of nursing homes cited for violating the regulations received either no penalties or only small fines (Cenziper et al, 2020). Not surprisingly, studies would reveal that COVID-19 cases were on a per capita basis much more numerous in for-profit nursing homes than in their greatly outnumbered government-run and nonprofit cousins (Novotney, 2020).

The profit-seeking tendencies of legally sanctioned nursing homes were major accomplices in the COVID-19 tragedy. As noted earlier, in order to hold down costs the nursing-home industry had come to rely heavily on poorly-trained and poorly-paid nursing aides to staff the nursing homes. In some cases, the nursing aides' limited training resulted in a failure to appreciate proper procedures and in faulty or misguided care. This, in turn, could and did contribute to the spread of the disease and ultimately to an increased number of deaths.

In addition (and as noted before), nursing aides are usually paid only the minimum wage required by 
law, and, because of these low wages, many nursing aides work in more than one nursing home at a time. Sometimes nursing aides take consecutive shifts in a nursing home on one side of town and then in a different nursing home on the other side of town. Some work in more than two nursing homes. Estimates are that the average nursing home has staff connections at 15 other nursing homes (de Freytas-Tamura, 2020). These connections and the movement of staff members from one home to another contributed to the COVID-19 disaster because the nursing aides have in some cases carried the disease from one nursing home to another (Elder Law Answers, 2020; Kim, 2020). Even after many nursing homes prohibited friends and family members from visiting residents in hopes of keeping out the virus, staff members working at multiple nursing-home sites remained "pathways" for coronavirus infections (de Freytas-Temura, 2020, p. A8).

Once inside the walls of a nursing home, COVID-19 often spreads even more quickly than the skin infections, respiratory infections, and gastroenteritis that have perennially plagued for-profit nursing homes. After all, COVID-19 transmission takes place via undetectable droplets passing through the air from an infected person to someone not previously infected. The transmission is especially likely if masks are not worn or worn improperly, but many infected people are asymptomatic and do not even stop to consider mask-wearing. Cost-cutting steps such as double or triple rooms, shared bathrooms, and group recreation and eating areas are ideal settings for one resident to transmit the disease to another.

The best way to stop the spread of COVID-19 would be an infection control program that was well designed and effectively utilized, but for-profit nursing homes in particular are notorious for their poor infection control programs. An effective infection control program would of course take time and money and cut into the nursing homes' profits. What's more, the nursing homes were actively lobbying the Trump Administration to roll back infection control requirements at the time the pandemic struck (Edelman, 2018).

Beyond subjecting their residents to ill-prepared and sometimes infected staff members and failing to practice effective infection control, the nursing-home industry has seen COVID-19 as an opportunity to improperly evict some residents and replace them with COVID-19 patients. In fact, for-profit nursing homes jumped on the opportunity. Mike Wasserman, a former CEO of a California for-profit chain said the pandemic has "supercharged illegal evictions" (Silver-Greenberg \& Abrams, 2020, p. 1).

Why would for-profit nursing homes be willing to take on COVID-19 patients and further expose current residents to new residents who had been infected? The standard justification is that it would ease the burden on overwhelmed hospitals, that is, hospitals with more coronavirus patients than they could supposedly manage (Sapien \& Sexton, 2020). An ignoble secret, meanwhile, is that many of the evicted 
patients paid their tabs through Medicaid, while the coronavirus patients were covered by Medicare, for which the payments are substantially higher. Medicare payments for COVID-19 patients can be as much as $\$ 600$ a day more per patient (Silver-Greenberg \& Harris, 2020).

Because of the deaths among those transferred from hospitals to nursing homes and because of deaths from COVID-19 in nursing homes in general, lawsuits against nursing homes have increased dramatically since the start of the pandemic. Most of the defendants are of course for-profit nursing homes, which, as always, cut corners in hopes of holding down costs (Meyer, 2020). The lawsuits rely on state nursing-home resident protection statutes as well as on general common law negligence principles. One COVID-19 lawsuit tracker shows that as of September 2020, 55 wrongful death lawsuits had been filed against long-term care facilities around the country (Meyer, 2020).

The numbers are striking because even in normal times pursuing a lawsuit against a nursing home is difficult. Potential plaintiffs are usually older, sickly adults and may not live long enough for years of litigation. Then, too, their resources are often small or dwindling. Add to these problems the fact that litigation in general has been slowed in American courts during the pandemic.

The chances of a plaintiff getting into the courtroom with a COVID-19-related claim are indeed even slimmer because specific legisla- tion attempts, figuratively speaking, to block the entrance to the courtroom. At least 26 states (including Illinois, Michigan, New Jersey, and New York) have enacted immunity laws that protect nursing homes from negligence lawsuits arising from shortages of protective equipment, staffing problems, or minimally faulty care. These statutes, in other words, bar claims for standard negligence related to acts or omissions that occurred after various states declared public emergencies in the spring of 2020 (Harris et al, 2020; Meyer, 2020).

For the most part, only lawsuits alleging "gross negligence" will be allowed to go forward (Harris et al., 2020, p. A13). These lawsuits can result in punitive damages, which unlike regular damages, are not meant to compensate a plaintiff for specific losses but rather are designed to punish a defendant for especially outrageous conduct. However, proving gross negligence in a court of law is extremely difficult. A plaintiff has to show that the defendant's conduct fell below the level of care that even a reckless person might have been expected to provide. Few nursing-home residents will be able to show that a nursing home and its staff deliberately and absolutely disregarded the residents' health and safety (Meyer, 2020).

Regardless of the success of the lawsuits, families have grown leery of putting older relatives in for-profit nursing homes. Nursing home occupancy fell 10.9 percent between February and August of 2020 (Brubaker, 2020). Did this decline in occupancy figures once and for all lead nurs- 
ing-home executives to vow they would make changes in the care they provided and in their operations generally? Alas, the chief concern seemed to be for nursing homes' financial viability given decreasing demand (Brubaker, 2020). A few of the largest nursing-home businesses sought government grants and loans to help stay afloat despite the pandemic. The previously discussed Genesis HealthCare, for example, received a $\$ 180$ million grant under the Coronavirus, Aid, Relief, and Economic Security Act plus \$27 million in state funding. The nursing-home giant also received $\$ 158$ million in advance Medicare payments, an amount that can be thought of as a generous loan from the federal government (Goldstein, 2020).

\section{Conclusion}

I $n$ the course of the twentieth century and especially after the passage of Medicare and Medicaid legislation in the mid-1960s, a sprawling and profitable nursing-home industry came to dominate nursing-home care for older adults. Relying on corporate ownership structures, sometimes disingenuous business dealings, and a willingness to quickly and sternly evict residents who were delinquent in their payments, for-profit nursing homes came to constitute one of the nation's largest service industries.

However, we have known for decades that the care in for-profit nursing homes is on average inferior to that in the much less numerous state-run and nonprofit nursing homes. For-profit nursing homes frequently cut costs related to maintenance, staffing, and infection control in hopes of increasing their profits. Many residents are left to suffer from the incessant profit-seeking.

Congress finally attempted to address these problems during the late 1980s and early 1990s, enacting a substantial body of law and even a Residents' Bill of Rights. These enactments were largely exhortative, but federal regulators buoyed the statutory pronouncements with detailed and frequently revisited regulations. Unfortunately, the regulations were weakly enforced and sometimes not enforced at all. In the end, the federal laws and regulations served to legitimize the problematic for-profit nursing home as a passable institution in American life.

The core problem in the area is the profit-seeking practices of nursing homes, and it is difficult to imagine the alteration of this fundamental reality, especially given the overall magnitude and political clout of the nursing-home industry. But still, with the COVID-19 pandemic nearing the end and a new Administration at the helm in Washington, D.C., the time is perhaps right for policy changes and the reinforcement of those changes through laws and regulations.

Reformers might undertake the following:

1. Attend carefully to whom is admitted and evicted from nursing homes. In particular, "dumping" Medicaid residents in favor of residents whose assets or private 
insurance policies enable them to pay more should be prohibited.

2. Enhance the training and education of nursing-home staff. The people who work in nursing homes provide what are often life-or-death services for the residents, and these services should be of a higher quality.

3. Increase the compensation of nursing-home staff and especially of nursing aides. The latter should be able to earn enough and receive sufficient benefits to support their families while working at a single nursing home.

4. Create and revise federal regulations with an eye to improved care rather than to proprietors hopes for reduced costs. The Trump Administration's attempt to make infection-control regulations less stringent was especially revealing, but in general the influence of the nursing-home industry in federal regulation bears close monitoring.

5. Subsidize nonprofit and staterun nursing homes to the extent possible. Studies have found that the quality of care is on average better in these types of facilities than in the larger and more numerous for-profit nursing homes.

No single policy change is a panacea for the problems that plague nursing-home care in the United States, but all of these policy recommendations would be steps in the right direction. While the cause of death for many nursing home residents during 2020 and 2021 has officially been listed as COVID-19, legally sanctioned, for-profit nursing homes set the stage for the disaster. Changes should be made before the next severe health crisis and, more generally, to protect the dignity and humanity of America's nursing-home residents during the final years of their lives.

\section{Acknowledgments}

The author thanks Amanda Meyers, Marquette Law '21, and Julia Mikota, Marquette Law '20, for excellent research assistance in conjunction with this article.

\section{References}

Adler, J. (2003, July). For-profit or non-profit? What's the difference? Chicago Tribune. Retrieved from https://www.chicagotribune.com/news/ct-xpm2003-07-20-0307200309-story-html.

Archer, D. (2020, May). Coronavirus: Should nursing homes be for-profit? Just Care. Retrieved from https://www.justcareusa.org $>$ category $>$ what's buzz ing/long-term-care/. 
Barkan, S. (2009). Law and society: An introduction. Upper Saddle River, NJ: Pearson Prentice Hall.

Barker, K. (2020, June). 64 days under siege at a nursing home. New York Times, A11.

Black, D. (1976). The behavior of law. New York: Academic Press.

Brubaker, R. (2020, November). After COVID-19, families wary of placement in nursing homes. Milwaukee Journal Sentinel, 2C.

Center for Medical Advocacy. (2012, March). Non-profit vs. for-profit nursing homes: Is there a difference in care? Center for Medical Advocacy. Retrieved from https://www.medicalcareadvocacy.org/non-profit-vs-for-pro fit-nursinghomes-is-there-a-difference-in-care.

Cenziper, D., Jacobs, S., \& Mulcahy, S. (2020, October). As pandemic raged and thousands died, government regulators cleared most nursing homes for infection-control violations. Washington Post. Retrieved from https:www. washingtonpost.com/business/2020/10/29/nursing-home-deaths-fines/.

de Freytas-Tamura, K. (2020, September). States are looking at nursing homes as carriers. New York Times, A8.

Dearborn, M. (2009). Enterprise liability: Reviewing and revitalizing liability for corporate groups. California Law Review, 97(1), 195-261. doi:10.15779/ z384Q41.Corpus Id: 54946496

Drucker, J. \& Silver-Greenberg, J. (2020, March). Regulation intends to relax oversight in nursing homes. New York Times, B6.

Edelman, T.S. (2018, January). Deregulating nursing homes. Bifocal, 39(3), 31-33.

Eilperin, J. \& Cameron, D. (2018, January). How Trump is rolling back Obama's legacy. Washington Post. Retrieved from https://www.wahingtonpost.com/ graphics/politics/trump-rolling-back-obama-rules.

Elder Law Answers. (2020, October). How low nursing home wages are contributing to COVID-19's spread. Elder Law Answers. Retrieved from https: www. elderlawanswers.com/how-low-nursing-home-wages-are-contributingto-the-spread-of-covid-19-17702.

Engelhart, K. (2019, November). Some nursing homes are illegally evicting elderly and disabled residents who can't afford to pay. NBC News. Retrieved from nbcnews.com/news/us-news/some-nursing-homes-are-illegally-evictingelderly-and-disabled-residents-who-can't-afford-to-pay-n1087341.

Ferré-Sadurni, L. \& Harris, A. (2020, July). Does Cuomo share blame for nursing home deaths? New York Times, 4. 
Fieldstadt, E. (2019, August). Nursing home staffers accused of taunting 91-yearold dementia patient in snapchat video. NBC News. Retrieved from $\mathrm{n} \mathrm{b} \mathrm{c} \mathrm{-}$ news.com/news/us-news/nursing-home-staffers-accused-of-taunting-91year-old-dementia-patient-in-snapchat-video-n1041366.

Fortune 500. (2020, May). Genesis Healthcare. Fortune. Retrieved from https:// www. fortune.com/company/genesis-healthcare/fortune500/.

Goldstein, M. (2020, September). Nursing home giant gets over $\$ 300$ million in aid. New York Times, B1.

Goldstein, M. \& Gebeloff, R. (2020, September). Crisis pushes elder homes to the brink. New York Times, B1.

Goldstein, M., Silver-Greenberg, J., \& Gebeloff, R. (2020, May). Setting aside quality care for a profit. New York Times, B1, B6.

Gonzales, L. (2020). Infection control in nursing homes. Claude Pepper Center. Retrieved from https:www.claudepeppercenter.fsu.edu/research/policy-is sue-briefs/infection-control-in-nursing-homes/.

Grabowski, D. (2007). Medicare and Medicaid: Conflicting incentives for longterm care. Milbank Quarterly, 85(4): 579-610. doi:10.1111/j.1468-009.20 07.00502x

Grabowski, D. \& Mor, V. (2020). Nursing home care in crisis in the wake of COVID-19. Journal of the American Medical Association, 324(1), 23-24. doi:10.1001/jama.2020.8524

Grant, R. \& Smetanka, L. (2020). Residents in skilled nursing facilities face growing concerns over evictions. Bifocal, 41(3), 200-03.

Harrington, C., Hauser, C., Olney, B., \& Rosenau, P.V. (2011). Ownership, financing, and management strategies of the ten largest for-profit nursing home chains in the United States. International Journal of Health Services, 41:4 (2011), 725-46. doi:10.2190/HS.41.4g

Harris, A., Barker, K., \& McKinley, J. (2020, May). New York gives nursing homes liability shield. New York Times, A1, A13.

Hawes, C. \& Phillips, C. (1986). The changing structure of the nursing home industry and the impact of ownership on quality, cost, and access. Washington, D.C.: National Academies Press.

Heiser, K.G. (2020). Understanding nursing home discharge regulations and residential rights. Aging Care. Retrieved from https://www.agingcare.com/ topics/184/skilled-nursing-facility/ aticles. 
Howley, E.K. (2020, November). Nursing home facts and statistics. U.S. News. Retrieved https://www.health.usnews.com/health-news/best-nursinghomes/articles/nursing-home-facts-and-statistics.

Khimm, S. \& Strickler, L. (2020, March). Amid outbreak, Trump administration's proposed rollback of nursing home regulations faces criticism. NBC News. Retrieved from https://www.nbcnews.com/us-news/amid-outbreak -Trump-administrations-proposed-rollback-of-nursing-home-regula tions-faces-criticism-n1147661.

Kim, E.T. (2020, July). 13 hours' pay for a 24-hour shift. New York Times, A25.

Klauber, M. \& Wright, B. (2020). The 1987 nursing home reform act. Public Policy Institute. Retrieved from https://www.aarp.org/home-garden/livable-com munities/info-2001/the_1987_nursing_home_reform_act.html.

Laws, G. (1993). “The land of old age": urban built environments for elderly people. Annals of the Association of American Geographers, 83(4), 672-93. doi:10.1111/j.1467-8306.1993.tb01960.x

Leland, J. (2020, April). Nursing homes nearing crisis in coronavirus pandemic. New York Times, 28.

Margolies, J. (2020, May). A powerful case for smaller nursing homes. New York Times, B7.

Meyer, H. (2020, October). A question of neglect? American Bar Association Journal, 46-53.

Novotney, A. (2020, June). Residents in for-profit nursing homes face higher COVID-19 risk, study finds. McKnight's Senior Living. Retrieved from https://www.mcknightsseniorliving.com/business-daily-news/residentsin-for-profit-nursing-homes-face-higher-COVID-19-risk-study-finds/.

Nursing Home Abuse. (2020, June). Understanding nursing home abuse. Nursing Home Abuse Center. Retrieved from https://www.nursinghomeabusecentr. com/nursing-home-abuse/\#content-heading-O.

Nursing Home Reform Act, 42 U.S.C. \$1396r (1987).

Papke, D. R. (2019). Containment and condemnation: Law and the oppression of the urban poor. East Lansing, MI: Michigan State University Press.

Rau, J. (2020, January). Care suffers as more nursing homes feed money into corporate webs. Washington Post. Retrieved from https://www.washingtonpost. $\mathrm{com} /$ national/health-science/care-suffers-as-more-nursing-homes-feedmoney-into-corporate-webs/2017/12/31/3b782068-ee91-11e7-95c3-eff $284 \mathrm{e} 71 \mathrm{c} 8 \mathrm{~d} /$ story/hml. 
Rau, J. (2020, May). Trump administration announces new scrutiny for nursing homes. Shots: Health News from NPR. Retrieved from https://www.npr. org/sections/health-shots/2020/03/05/812359226/trump-administration-announces-new-scrutiny-for-nursing-homes.

Requirements for State and Long-Term Care Facilities, 42 C.F.R. $\$ 483$ (1989).

Rincon del Rio. (2017, June). The history of nursing homes: From almshouses to skilled nursing homes. Rincon del Rio. Retrieved from https://www.rincondelrio.com/the-history-of-nursing-homes-from-almsouses-to-skillednursing-homes.

Robbins, R. (2021, January). Vaccine's slow path to nursing homes. New York Times, B1, B6.

Sapien, J. \& Sexton, J. (2020, June). "Fire through dry grass": Andrew Cuomo saw COVID-19's threat to nursing homes. Then he risked adding to it. Pro Publico. Retrieved from propublico.org/article/fire-through-dry-grass.

Silver-Greenberg, J. \& Abrams, R. (2020, September). Nursing homes seize pretexts to evict the poor. New York Times, 1, 6 .

Silver-Greenberg, J. \& Harris, A. (2020). As crisis swirls, nursing homes "dump" patients. New York Times, 1, 8.

Span, P. (2020, June). Navigating home aid during the pandemic. New York Times, D3.

Stevenson, D. (2018, August). The future of nursing home regulation: Time for a conversation? Health Affairs Blog. Retrieved from https://www.healthaffairs. org/do/10.1377?hblog20/80820.660365fall/. doi:10.1377/hblog20180820.6 60365

Stevenson, D., Bramson, J.S., \& Grabowski, D. (2013). Nursing home ownership trends and their impact on quality of care: A study using detailed ownership data from Texas Journal of Aging \& Social Policy, 25(1), 30-47. doi: 10.1080/08959420.2012.705702

Weinmeyer, R. (2014, May). Statutes to combat elder abuse in nursing homes. Virtual Mentor. 16(5), 359-64. doi:10.1001/virtualmentor.2014.16.05.hlaw11405

Wilson, K.B. (2007, November). Historical evolution of assisted living in the United States. The Gerontologist, 47(3, suppl. 1), 8-22.

Wright, B. (2001). Federal and state enforcement of the 1987 nursing home reform act. AARP Public Policy Institute. Retrieved from https://www.aarp.org/ home-garden/livable-communiteis/info-2001/federal_and_state_enforce- 
ment_of_the_1987_nursing_home_reform_act.html.

Zheng, X. \& Grabowski, D. (2004). Nursing home staffing and quality under the nursing home reform act. The Gerontologist, 44(1), 13-23. doi:10.1093/ geron/44.1.13 